\title{
振動流や回転流の境界層に引き起こされる物質分散 \\ Matter Dispersion Due to Boundary Layers in Oscillatory and Rotating Fluid
}

安田秀-

By Hidekazu YASUDA

\begin{abstract}
Matter dispersion due to the shear effect of currents is investigated theoretically as one of the mixing dilution processes. The shear is generated in the boundary layer as Stokes or Ekman laver which is given by motion equations. Dispersion of suspended matter with its own settling velocity is also analyzed besides that of passive matter. Both kinds of matter are strongly dispersed only in the boundary layers at the initial stage. As the time proceeds, the dispersion coefficient of passive matter gets inversely proportional to the water depth in the oscillatory current, while that of suspended one with a certain settling velocity is independent of the depth and fairly larger than that of passive one. However the dispersion coefficient of suspended matter gets slightly larger with increase of the water depth although that of passive one is not so dependent on it as suspended one. Keywords: longitudinal and horizontal dispersion. Stokes layer, Ekman layer, vertical structure.
\end{abstract}

\section{1.まえがき}

シアー効果による物質分散については、G.I.Taylor の偉大な業績 ${ }^{12}$. 2) の後、多くの流体力学に携わる研究 者らによって解析されてきた。これまでの殆どの研究は、流れの全領域に注目して分散係数を評価すること が多かったが、本研究は、潮汐の卓越する閉鎖性海域の物質輸送過程の解明を主要課題として、代表的なシ アー領域である境界層を着目し、新しい定義や概念を導入しながら、その基本特性を明らかにしようとする ものである。本報では、シア一効果による物質分散は見かけの現象ではなく、主要な混合希釈過程の一つで あるとの観点で解析を進める。

\section{2. 物質分散の解析手法}

シアー効果による物質分散を解析するための、物質濃度 $S(x, y, z, t)$ を支配する移流払散は、水平拡散を無 視して次のような式で支配されるものとする。

$$
S_{t}+u S_{x}+v S_{y}+w S_{z}=k S_{z z}
$$

$u, v$ は $x, y$ 方向の流れの成分で、wは拡散物質自身の銛直方向の速度である。添字の $x, y, z, t$ は、それぞれ の方向の微分を示す。 $k$ は鉛直方向の拡散係数である。流れは水平方向には一様で、物質の鉛直速度は $z$ 方

* 正会員 理博 通商産業省 工業技術院 中国工業技術研究所 海洋環境制御部 海洋動態研究室 （干737-01 広島県呉市広末広 2-2-2） 


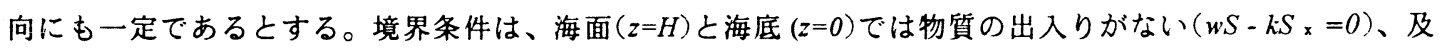
び水平方向の無限遠では濃度は 0 とする。初期条件については、 $x=0, y=0$ における瞬間線源と間点源 $(z$ $=z$ o)を場合に応じて与えることとする。本研究では水平方向 $(x-y$ 平面)の二次元分散も対象とするが、 $y$ 方向の変動を無視した場合には、通常よく取り扱われる縦方向分散 $(x$ 方向)となる。水深が一定で流れが水

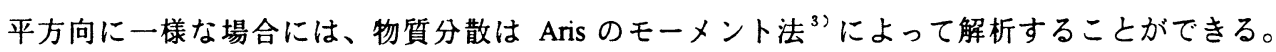

流れを支配する運動方程式は、次のように書き表されるものとする。

$$
u_{t}-f v=F_{x}+v u_{z z}, \quad v_{t}+f u=F_{y}+v v_{z z}
$$

式中の $f, \nu$ は、それぞれコリオリパラメー夕と粘性係数で、ここでは一定值とする。上式の各項は、シャ 一プなシアー領域である境界層が形成されるよう、以下において適宜用いられる。

\section{Stokes境界層を形成する振動流中の維方向分散}

繸方向分散を引き起こす $x$ 方向の振動流 $u(z, t)$ は、式(2)によって次のように求めることができる。

$$
u(z, t)=U\left[\left(1-e^{-\beta z} \cos \beta z\right) \sin \sigma t+e^{-\beta z} \sin \beta z \cos \sigma t\right]
$$

$U$ は振動流の振幅で $F x / \sigma$ に相当し、。は潮汐の基本振動数である。 $\beta$ は $(\sigma / 2 v)^{1 / 2}$ を表し、その逆数はス トークス境界層の代表寸法を意味している。これまでの振動流中の物質分散の多くは、運動方程式とは関わ りなく、単純化した流れを仮定して解析されているが4)．57．6)、流れについても払散方程式と同程度の精度 で考える必要があるのではないであろうか。実際の海域などでは、拡散代表時間は潮汐周期よりも遥かに長 く、従来から着目されている定常段階は、実際には殆ど目に留まることはない。現場海域は常に変動的で、 我々の印象に残る分散は、むしろ初期段階にあると言っても過言ではない。初期段階の分散を扱うときには、 式(4)のような境界首を考虑した流れ場における解析が、沿岸域の分散現象の基本的なプロセスを理解する上 で意義をもつのではないかと考える゙2,8》。

縦方向 ( $x$ 方向)の物質の拡がりを表す統計的分散值は、次のように求められる。

$$
\sigma_{x}^{2}(z, t)=\int_{-\infty}^{\infty}\left\{x-\mu_{1}(z, t)\right\}^{2} S(x, z, t) d x / M_{0}=\mu_{2}(z, t)-\mu_{1}(z, t)^{2}
$$

$\mu_{2}$ と $\mu_{1}$ は、それぞれ 0 次のモーメントで規格化された 2 次と 1 次のモーメントである。ちなみにp次のモ 一メント $M_{p}(z, t)$ は $\int_{-\infty}^{\infty} x^{p} S(x, z, t) d x$ のように定義される。任意の水梁と時刻における分散値 $(5)$ は、 $d \sigma_{x}^{2}(z$, $t) / 2 d t$ の定義のよって、水深と時間に依存する分散係数 $D \times(z, t)$ を導くことができる。

従来、鉛直平均分散係数 $\sigma_{\times}{ }^{2 *}(t)$ は、 $\mu_{2}-\mu_{1}{ }^{2}$ のように与えられるが（下線は鉛直積分を表す）、これは 物質濃度の鈶直積分值に基ついたもので、混合によって分散されたもののみではなく、流れのシアーによっ て引き伸ばされたものも分散值に中に含んでいる。物質分散は鉛直平均等による算術的な結果として起こる のではなく、分子搪散や乱流拡散に次ぐ混合過程であると考えると、従来の定義による統計的分散値は適当 とは思われない。混合希釈を表現する鉊直平均分散値 $\sigma_{x}^{2}(t)$ は、 $\sigma_{x}^{2}(z, t) M_{0}(z, t)=\underline{M_{2}}(t)-\left\{\underline{M_{1}(z, t)^{2} / M_{0}}\right.$ $(z, t)\}$ のように定義することができる。0次のモーメントは物質が鈴直的に不均一の分布しているときに考 慮する必要があるが、それが銛直的に一様な場合は、 ${\underline{\sigma_{x}}}^{2}(t)=\underline{\mu_{2}-\mu_{1}{ }^{2}}$ のよjになる。これらの各分散值 を前述のように時間微分することによって、対応する分散係数を導くことができる。

$x$ 方向の $p$ 次のモーメントを支配する方程式は、拡散方程式(1)に基ついて(6)のように書き表され、その 形式解は(7)のように導かれる。

$$
\begin{aligned}
& M_{p t}+w M_{p z}-k M_{p z z}=p u M_{p-l} \\
& M_{p}(z, t)=p \int_{0}^{t} \int_{0}^{z} G(z, t ; \xi, \tau) u(\xi, \tau) M_{p-l}(\xi, \tau) d \xi d \tau
\end{aligned}
$$




$$
\begin{aligned}
& G(z, t ; \xi, \tau)=\omega e^{\omega(z / H)} /\left(e^{\omega}-1\right)+\sum_{n=1}^{\infty} e^{K n(\tau-t)} E_{n}(z) F_{n}(\xi) / N_{n}^{2} / 2 \\
& E_{n}(z)=\omega e^{(\omega / 2)(z / H)} \sin p_{n} z+2 n \pi e^{(\omega / 2)(z / H)} \cos p_{n} z, F_{n}(\xi)=\omega e^{-(\omega / 2)(\xi / H)} \sin p_{n} \xi+2 n \pi e^{-(\omega / 2)(\xi / H)} \cos p_{n} \xi \\
& \omega=w H / k, N_{n}^{2}=(\omega / 2)^{2}+(n \pi)^{2}, K_{n}=N_{n}^{2} k / H^{2}=N_{n}^{2} / T_{c}, p_{n}=n \pi / H, T_{c}\left(=H^{2} / k\right)
\end{aligned}
$$

$G(z, t ; \xi, \tau)$ はグリーン関数で、0 次のモーメントを明らかにすることによって、順次、高次のモーメントを 求めることが可能である ${ }^{8)}$ 。本報では $w \neq 0$ は拡散物質が艓濁物質であることを示しており、w＝0の場合 は物質が passive(溶存物質)であることを示している。その場合のグリーン関数は次のように簡略化される。

$$
G(z, t ; \xi, \tau)=1+2 \sum_{n=1}^{\infty} e^{K n(\tau-t)} \cos p_{n} z \cos p_{n} \xi
$$

この場合の $K n$ は $k(m \pi / H)^{2}=(m \pi)^{2} / T c$ のよう簡略化される。繫濁物質及び溶存物質の 0 次のモーメントは、 それぞれ次のように求められる。（8）で示したように、いは全水深に着目した場合の無次元水深である。

$$
\begin{aligned}
& M_{0}(z, t)=\omega e^{\omega(z / H)} /\left(e^{\omega}-1\right)+\sum_{n=1}^{\infty} e^{-K n t} E_{n}(z) F_{n}\left(z_{0}\right) / N_{n}{ }^{2} / 2 \\
& M_{0}(z, t)=1+2 \sum_{n=1}^{\infty} e^{-K n t} \cos p_{n} z \cos p_{n} z_{0}
\end{aligned}
$$

ちなみに溶存物質が瞬間線源として投入された場合には、0 次のモーメントは常に 1 である。各モーメント にかかる係数 $S$ 。/H は単位量 1 と見なして省略する。

図一1は、溶存物質を瞬間線源として投入した場合の、海面と海底における分散係数の時間変化を描いたも のである。破線は、太いものが本報で定義した混合の程度を表す鉊直平均分散係数で、細い破線は従来の定 義による流体要素の伸び(または变形)を含んだものである。但し水深 $H^{*}(-\beta H)$ は10で、拡散係数と粘性係 数を等しいとすると、結果的に銛直方向の拡散代表時間と潮汐周期の比 $T_{\mathrm{r}}\left(=T_{\mathrm{c}} / T\right)$ は 31.83 となる。この比 が 1 よりかなり大きい場合には、振動流による分散は無視できるほど小さい5，67とされてきたが、特に初期 の段階では、シア一領域に接する海底では必ずしも小さいとは言えない。またこの図は、定常段階では周期 平均值は同しになるものの、周期内の変動は各場合で大きく異なっていることを示している。むう一つ注目 すへきことは、従来の定義による鈶直平均分散係数は負になることはあるが、ここで定義された混合の程度 を表す分散係数は、決して負になることはないということである。

定常段階の鉊直及び周期平均分散係数は、周期変動を除いて、 $\exp \left(-K_{\mathrm{n}} t\right)=0$ を考慮することによって、 下記のように求めることができる。

$$
\begin{aligned}
D_{s}= & U / \sigma \sum_{n=1}^{\infty} K_{n} \sigma /\left(K_{n}^{2}+\sigma^{2}\right)\left[\left\langle-\left\{H^{*} /\left(H^{* 2}+\left(H^{*}+n \pi\right)^{2}\right)+H^{*} /\left(H^{* 2}+\left(H^{*}-n \pi\right)^{2}\right)\right\} / 2\right\rangle^{2}\right. \\
& \left.+\left\langle-\left\{\left(H^{*}+n \pi\right) /\left(H^{* 2}+\left(H^{*}+n \pi\right)^{2}\right)+\left(H^{*}-n \pi\right) /\left(H^{* 2}+\left(H^{*}-n \pi\right)^{2}\right)\right\} / 2\right\rangle^{2}\right]
\end{aligned}
$$

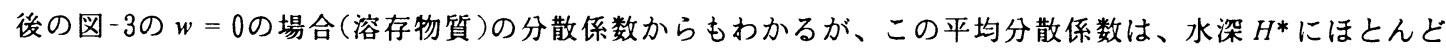
反比例している。このことは、水深が大きいほどシア一領域が相対的に狭くなることからすると、理にかな

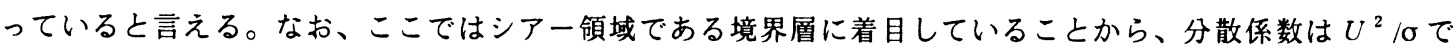
規格化されるが、通常の全水梁に着目した場合の $U^{2} T$ cを係数とした分散係数は、前者を $2 \pi T r\left(=2 H^{* 2}\right) て ゙$ 割 ることによって求めることができる。

沈降速度を持つ䇣濁物質の場合には、分散係数の振る舞いはかなり異なってくる。図 -2 は $\omega(=w H / k)=-5 の$ 沈降性物質を、海面で点源投入した場合の鈶直平均分散係数の時間变化を描いたものである。実線と破線は、 それぞれ本報で定義したものと従来の定義によるものを表している。図中の左上の図は 0 次のモーメントの 鈶直分布を各時間(潮汐周期)毎に描いたもので、この四によると、時間の経過と共にストークス層領域に物 質が分布することによって、分散係数が大きくなっていく样子が認められる。定常段階においては、図-1の 溶存物質の場合より分散係数は大きくなっている。慜濁物質の場合の分散係数の定常值は、かなり繁雑には なるが、溶存物質の場合と同様の手続きによって次のように求められる。 
図-1 振動流中に瞬間線源で 放流された溶存物質の分散 係数の時間変化 太い実線：海底 細い実線：海面 太い破線：混合希釈のみを 表す鉛直平均值 細い破線：従来の鉛直平均 值
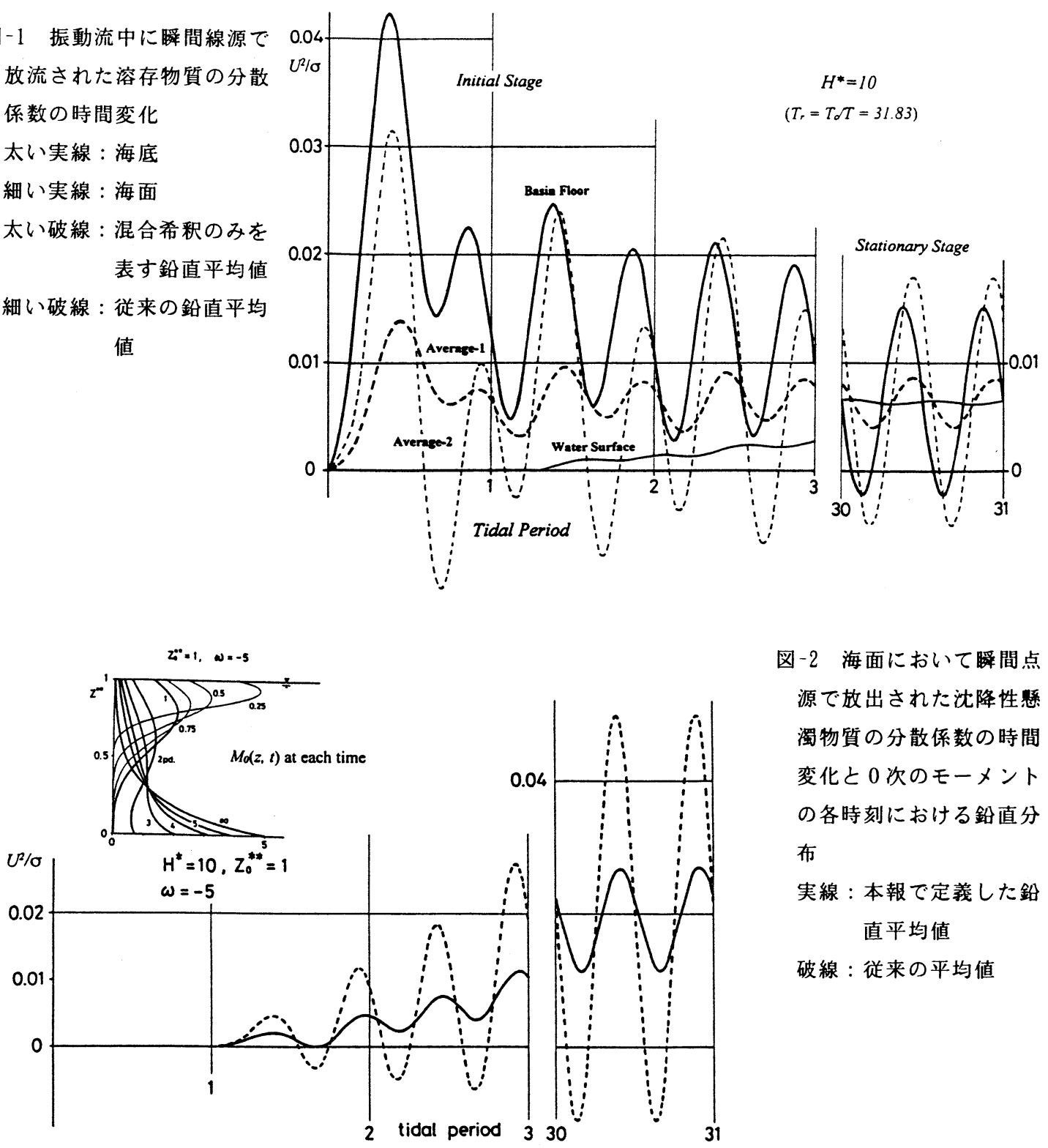

図-2 海面において瞬間点 源で放出された沈降性䋰 濁物質の分散係数の時間 変化と 0 次のモーメント の各時刻における鉊直分 布

実線：本報で定義した鉛 直平均値

破線：従来の平均値

図-3 振動流中の䱈濁物質の 分散係数の定常值：沈降速 度への依存性

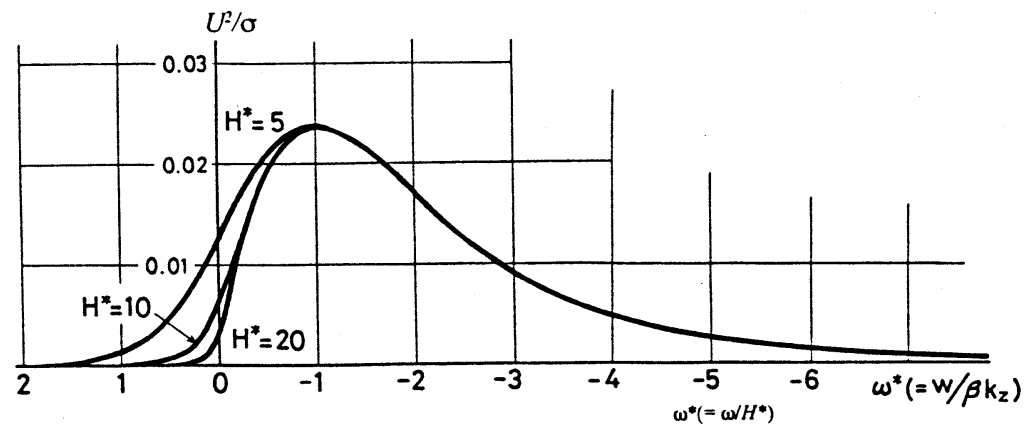




$$
D_{s}=U / \sigma \omega /\left(e^{\omega}-1\right) / 2 \sum_{n=1}^{\infty} K_{n} /\left(K_{n}^{2}+\sigma^{2}\right)\left(P_{n}^{2}+Q_{n}^{2}\right) / N_{n}^{2}
$$

$P_{n}=\int_{0}^{H} \alpha_{1 n}(\xi) \eta_{1}(\xi) d \xi+\int_{0}^{H} \alpha_{2 n}(\xi) \eta_{1}(\xi) d \xi, \quad Q_{n}=\int_{0}^{H} \alpha_{1 n}(\xi) \eta_{2}(\xi) d \xi+\int_{0}^{H} \alpha_{2 n}(\xi) \eta_{2}(\xi) d \xi$

$\alpha_{1 n}(\xi)=\omega e^{(\omega / 2)(\xi H)} \sin p_{n} \xi, \alpha_{2 n}(\xi)=2 n \pi e^{(\omega / 2)(\xi / H)} \cos p_{n} \xi, \eta_{1}(\xi)=1-e^{-\beta \xi} \cos \beta \xi, \eta_{2}(\xi)=e^{-\beta \xi} \sin \beta \xi$

図一3は、懸濁物質の定常段階における分散係数を、沈降速度の関数として描いたものである。横軸の沈降速 度はストークス層に着目して無次元化したものであるが、この $\omega^{*}(=w / \beta k)$ は $\omega(=w H / k)$ とは、 $\omega^{*}=\omega / H^{*}$ の関

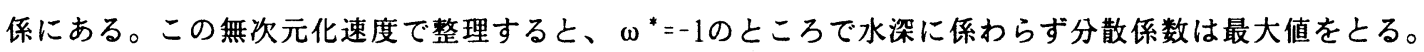
この時には物質は境界層近辺に分布しており、実質的な鉛直方向の拡散代表時間はかなり短くなって、境界 層のシアー効果を効率的に受けている。鉊直的に不均一に分布する物質の分散係数は水深に拘わらず、物質 が境界首の周辺に如何に分布しているかによるといえる。先にも述へたように、 $\omega^{*}=0$ 0溶存物質を意味 しており、この時には分散係数は水梁 $H^{*}$ に反比例していることが認められる。これらのことは、海底や陸 岸 $(z$ 軸を水平横方向とした場合)から投入された物質が、初期の段階では海底や陸岸の境界首によって大き な分散係数を持ちうることを意味している9”。

\section{Ekman境界層を形成する定常流中の水平分散}

地球自転効果は、定常流の場合でもエクマン境界層を形成する。この境界層内では流れは二次元的なシア 一構造を持ち、それによる物質分散は水平二次元的に引き起こされる。この二次元的な分散を表現するには、 新たに 0 次、1 次、2 次のモーメントを、それぞれ $M 0(z, t)=\iint_{-\infty}^{\infty} S\left(x_{i}, x_{j}, z, t\right) d x_{i} d x_{j}, M_{i}(z, t)=\iint_{-\infty}^{\infty} x_{i} S\left(x_{i}\right.$, $\left.x_{j}, z, t\right) d x_{i} d x_{j}, M_{i j}(z, t)=\iint_{-\infty}^{\infty} x_{i} x_{j} S\left(x_{i}, x_{j}, z, t\right) d x_{i} d x_{j}$ のように定義する必要がある。添字の $i, j$ は $x$ 方向、ま たは $y$ 方向を表す。ここで 2 次のモーメント $M_{i j}(z, t)$ は次のような方程式で支配される。

$$
M_{i j t}+w M_{i j z}-k M_{i j z z}=u_{i} M_{j}+u_{j} M_{i}
$$

ここでも $w=0$ のときは溶存物質を示すものとする。ここで新たに導入される共分散 $\sigma_{x y}{ }^{2}(z, t)$ は $\iint_{-\infty}^{\infty}\left\{x-M_{x}(z\right.$, $t)\}\left\{y-M_{y}(z, t)\right\} S(x, y, z, t) d x d y=M_{x y}-M_{x} M_{y} \quad$ で定義される。二次元的な分散值の表現には、各方向 成分の分散值の代数平均や幾何平均を用いる必要がある。代数平均をとった場合は方向性の問題は生じない が、単に引き延ばされたものも分散值の中に含まれる。幾何平均の場合は、分散の主軸の方向と座標軸がー 致しない時は、特に棈円状に分散した場合にその值が過大評価される。海洋乱流拡散における円形パッチ理 論に対応する二次元分散値 $\sigma_{\Lambda}^{2}(z, t)$ は、次のように定義することができる。

$$
\sigma_{\Lambda}^{2}(z, t)=\sqrt{\sigma_{\xi}^{2} \sigma_{y}^{2}}=\sqrt{\sigma_{x}^{2} \sigma_{y}^{2}-\sigma_{x y}^{2}}
$$

添字の $\xi, \eta$ は、それぞれ二次元分散值の主軸(長軸)方向と短軸方向の成分を示す。 $x$ 座標軸を基準とした長 軸方向の角度を $\theta$ とすると、それは $\tan 2 \theta=2 \sigma_{x y}{ }^{2} /\left(\sigma_{x}{ }^{2}-\sigma_{y}{ }^{2}\right)$ の関係で求められる。式(15)の分散値より前 述と同样に、時間微分することによって二次元分散係数が定義される。混合希釈の程度を表す鉛直平均的な

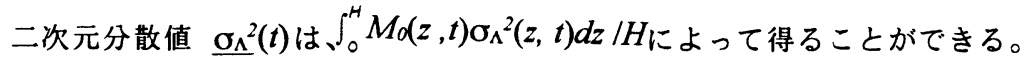

一样な風が $y$ 方向に吹いた場合の定常流は、式(2)と(3)の定常解として、次のように得られる。

$$
u(z)=U e^{-\beta z}(\cos \beta z+\sin \beta z), \quad v(z)=U e^{-\beta z}(\cos \beta z-\sin \beta z)
$$

$U$ は海面における流れの強さで、 $\beta$ はこの節においては $(f / 2 v)^{1 / 2}$ のことで、その逆数はエクマン境界層厚 の代表寸法を表す。前節の縌方向分散の場合とグリーン関数は同様で、流れも上記のように解析的に記述で きることから、それぞれのモーメントも前節と同様の手続きで導くことができる。

図-4 は、水深 $H^{*}=10$ において、瞬間線源として物質を投入した場合の、水平分散係数、主方向の分散 
係数、主軸方向の各々の鉊直分布を、初期段階から各時刻毎に描いたものである。回転流体の基本的な時間 である慣性周期 $T$ p は、拡散代表時間 $T$ cで置き換えると、 $\pi T c / H^{* 2}$ に相当する(前節の振動流の中では、振 動周期 $T=\pi T \mathrm{c} / H^{* 2}=T \mathrm{c} / 31.83$ になるこに対応)が、図によると、経過時間が $T$ 。 $/ 10$ 以前では分散係数は エクマン層の中 (シアー領域の厚さは $\beta^{-1}$ の約 3 倍)でのみで引き起こされて、主軸の方向も非常に変化に富 んでいるが、時間の経過と共に次第に層外でも分散が生じて、定常段階(通常 $t \geqq T 。 / 2$ )では、分散係数の みならずその主軸の方向も一樣になることが認められる。因みに $T$ 。は東京周辺で 21 時間に相当する。

円形パッチ理論や従来の定常流中の分散の解析結果との関連性を見るために、図-5に鈶直平均化した二次 元分散值(幾何平均)之主軸方向の分散值の時間変動を描いた。条件は図-4の場合と同様である。どちらの分 散値も定常段階においては時間に比例して大きくなるが、分散がエクマン層の中でのみ認められる $T$ 。 $/ 10$ 以前においては、分散値の增加は経過時間の 3 乗に比例しており、このことは乱流拡散が慣性領域にある時 の振る舞いに類似して興味深い。Okubo ${ }^{102}$ は無限に広がる海の中におけるシアー拡散を解析し、3 乗則を 提示したが、これらのことから、シアー効果による物質分散における分散值は、分散現象が底(境界)に達す るまでは、時間の 3 乗に比例して增加すると言える。

海底上を定常流が流れた場合にも、海底上にエクマン境界層が形成される。これによる解析結果は上記の 吹送流によるものを適当に座標変換することによって導き出すことができるが、ここで、エクマン層を伴う 流れ場における沈降性の懸濁物質の分散の挙動について検討する。境界層の上部で定常流が $x$ 方向に一樣に 流れる場合には、流れは次のように解くことができる。

$$
u(z)=U\left[1-e^{-\beta z} \cos \beta z\right], \quad v(z)=U e^{-\beta z} \sin \beta z
$$

エクマン層周辺の物質の分布状態と分散係数の関連性を知るために、定常段階における分散係数の沈降速度

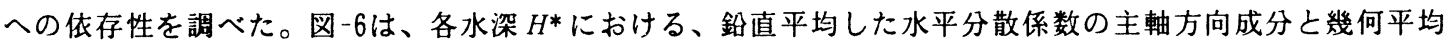
值(下部の破線)を沈降速度の関数として描いたものである。無次元化沈降速度は、全水深に着目したもの $\omega$ $(=w H / k)$ と境界首厚を着目したもの $\omega *(=w / k)$ が考えられるが、前節の振動流の場合のように後者で整理す ると、各水深における分散係数の主軸方向成分が最大值をとる時の沈降速度の值が著しく変動するが、図の ように前者をとると、水深の增加に従って(シアー領域が薄くなると共に)、最大值をとる沈降速度の値が $\omega$ $=-6$ 付近に収束する傾向が認められる。 $\omega=0$ の場合(溶存物質)は、振動流の時のように分散係数は水深 に反比例することはなく、むしろ水深が大きくなると、分散係数は徐々にではあるが大きくなっている。な おこれは、振動流の場合と同じように、境界層に着目して、分散係数を $U^{2} / f て ゙$ 整理した時の結果であるが、 従来のように全水深に着目した $U^{2} T$ 。係数とする場合の数値は、さらに $2 \pi T r\left(=2 H^{* 2}\right) て ゙$ 割ることによっ て得ることができる。その場合には $H^{*}$ が大きくなる程分散係数は小さくなるが、このことは振動流と定常 流の中の縦方向分散係数を比較した報告 ${ }^{11}$ の中で示された、「シアー領域が狭くなると分散係数が小さくな る」という結果と同じことを意味している。

境界層外では直線的に往復する振動流であっても、地球自転効果は境界層の中では横方向の流れも生成し、 潮流楕円を形成する ${ }^{12)}$ 。二次元分散の定義が明瞭になったことから、自転効果を取り入れた場合の、式(2) と(3)の解で示される振動流の中の愻濁物質の分散係数について検討する。

運動方程式の Fy 省略し、海域の幅が Rossby の変形半径よりも狭いとすると、流れの解は次のように得 られる。

$$
\begin{aligned}
& u(z, t)=\operatorname{Real}\left[U\left\{\left(1-f^{2}\right) e^{-(1-i) b z} / 2+\left(1-f^{2}\right) e^{-(1-i) a z} / 2-\left(1-f^{\prime 2}\right)\right\} e^{-i \sigma t}\right] \\
& v(z, t)=\operatorname{Real}\left[U\left\{\left(1-f^{2}\right) e^{-(1-i) b z} / 2-\left(1-f^{2}\right) e^{-(1-i) a z} / 2\right\} e^{-i \sigma t}\right]
\end{aligned}
$$

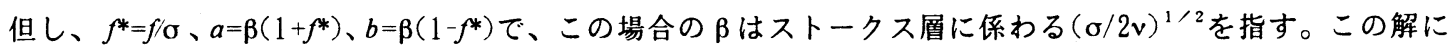
よる振動流は、先にも述へたように境界層内で潮流楕円を形成するが、その棈円率は $f^{*}$ の增加と共に大き 


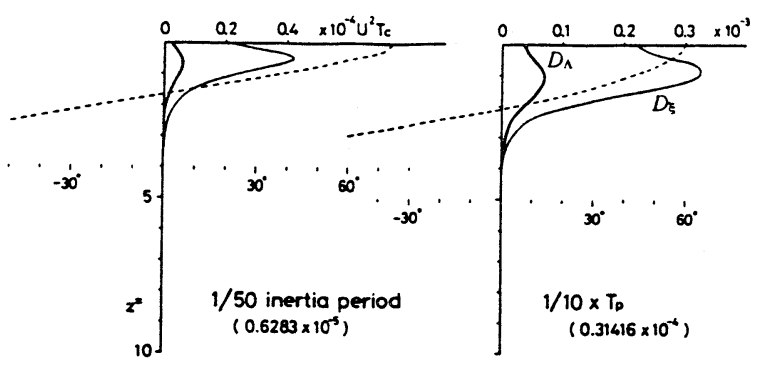

$T_{c}=\left(H_{E}^{* 2} / \pi\right) \times T_{p}$ cf $T_{c}=\left(H_{s}^{*} / \pi\right) \times T$

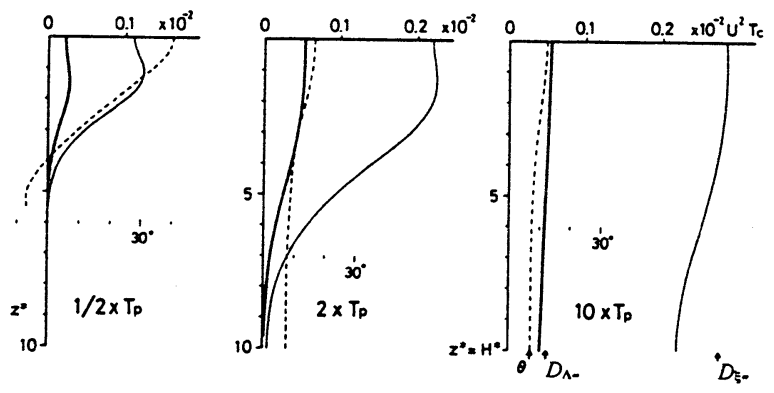

図-4 エクマン層を形成する吹送流による二次元分散係 数の鉊直構造の時間変動（太い実線：主軸幾何平均分 散係数、細い実線：主軸方向成分、破線：主軸の方向

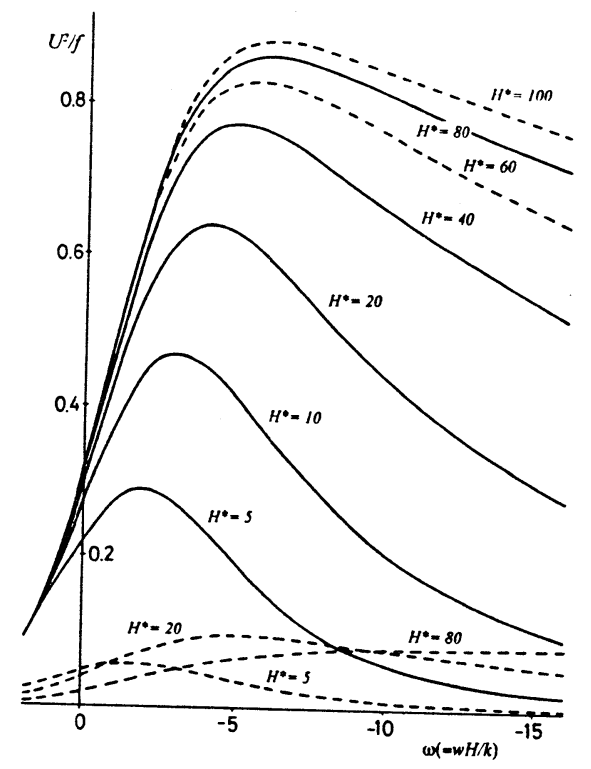

図-6 沈降速度に依存する、定常流中の分 散係数の主軸方向成分（定常値）

下の破線は幾何平均値を示す

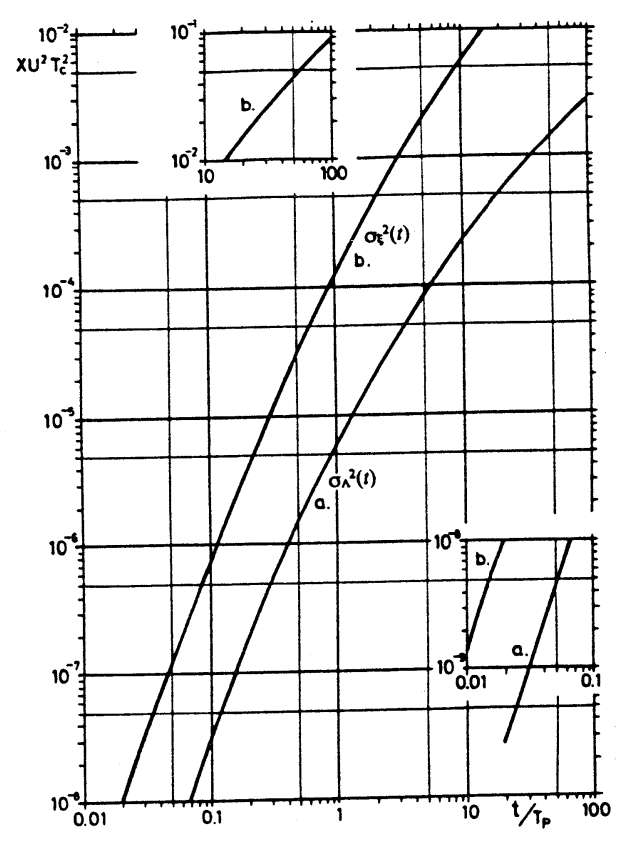

図-5 鉊直平均分散値の主軸方 向成分と幾何平均の時間変動

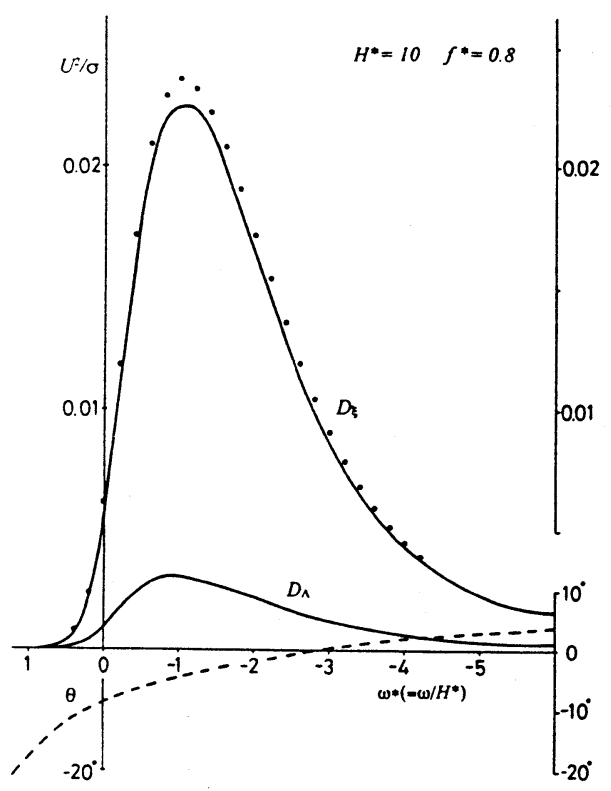

図-7 回転系の振動流中の定常分散係数 (主軸方向成分と幾何平均値) の沈降 速度への依存性: 破線は主軸の方向、 点は非回転の場合の縦方向分散係数 
くなる。図-7は $H^{*}=10, f^{*}=0.8$ (英国、オランダ周辺)の場合の、鉊直平均水平分散係数の主軸方向成分の値 と相乗平均值を、沈降速度の関数として描いたものである。破線はその時の主軸の方向を示している。実線 に沿う黒丸は、自転効果がない場合の縦方向分散係数で図-3のものに相当する。沈降速度は境界層に着目し た $\omega *$ で表しているが、 $H^{*}$ の値を乗じことによって、全図の場合の $\omega$ の値を知ることができる。ここで

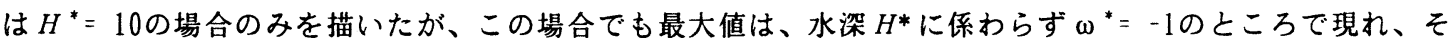
の值もほとんど変わらない。

\section{5.おわりに}

現実の流れの中の物質の分散過程は、三次元的でかなり複雑な現象であるために、分散過程を定量的に把 握して分散係数を算出することは困難なことが多い。物質分散は平均(積分)操作によって現象の詳細を省く ための概念ではなく、分子拡散、乱流拡散に次ぐ第三の物質混合過程であるとの観点から、そのプロセスを 簡略化したモテルの中で解析したが、現場海域の中におけるその意義を提起することができたのではないか と考える。ここで示した分散過程は、現場海域の中では、(1)海底近傍に漂う懸濁粒子の分散、(2)陸岸から放 出される污濁物質の分散、(3)陸に向かう風に吹き寄せられる物質の分散、(4)海面近くを漂う赤潮の風による 分散、(5)シャープな成層を形成する湖などにおける密度躍層付近の内部波による物質分散過程、等が考えら れるが、個々の過程については、それぞれの状況に応じて新たな条件を加味して解析する必要がある。

\section{参考文献}

1) Taylor,G.I.: Dispersion of soluble matter in solvent flowing slowly through a tube, Proc.Roy.Soc.London, Vol.A219, pp.186203, 1953.

2) Taylor,G.I.: The dispersion of matter in turbulent floe through a pipe, Proc.Roy.Soc.London, Vol.A223, pp.446-468, 1954.

3) Aris, R.: On the dispersion of solute in a fluid flowing through a tube, Proc.Roy.Soc.London, Vol.A235. pp.67-77, 1956.

4) Okubo,A.: The effect of shear in an oscillatory current on horizontal diffusion from an instantaneous source, Int.J.Oceanogr. Limnol., Vol.1, pp.194-204, 1967.

5) Holly,E.R., D.R.F.Harleman and H.B.Fischer: Dispersion in homogeneous estuary flow, J.Hydraul.Div.ASCE, Vol.96, pp.1691-1702, 1970.

6) Fukuoka,S.: Longitudinal dispersion of matter in alternating shear flow, Res.Bulletin C8, Dept.of Engineering, James Cook Univ. of North Queensland, 1973.

7) Yasuda,H.: Longitudinal dispersion due to the boundary layer in an oscillatory current: theoretical analysis in case of an instantaneous line source, J.Oceanogr.Soc.Japan, Vol.38, pp.385-394, 1982.

8) Yasuda.H.: Londitudinal dispersion of suspended particles in oscilatory currents, J.Mar.Res., Vol.47, pp.153-169, 1989.

9) Yasuda,H.: Longitudinal dispersion of matter due to the Stokes layer: its time-dependence in the case of an instantaneous point-source, J.Oceanogr.Soc.Japan, Vol.44, pp.244-253, 1988.

10) Okubo,A.: Some remarks on the importance of the "shear effect on horizontal diffusion", J.Oceanogr.Soc.Japan, Vol.24, pp.60-69, 1968.

11) Yasuda,H.: Longitudinal dispersion of matter due to the shear effect of steady and oscillatory currents, J.Fluid Mech., Vol.148, pp.383-403, 1984.

12) Yasuda H.: Vertical structure of the tidal current ellipse in a rotating basin, J. Oceanogr. Soc. Japan, Vol.43, pp.309-318, 1987. 